\title{
Permasalahan Makro dan Mikro dalam Pendidikan di Indonesia
}

\author{
Nur Laili \\ Email: 2010128120003@mhs.ulm.ac.id \\ Program Studi Pendidikan IPS Fakultas Keguruan dan Ilmu Pendidikan \\ Universitas Lambung Mangkurat \\ Banjarmasin
}

\begin{abstract}
This article aims to identify problems in education in Indonesia. Because it is hoped that understanding the educational problems that occur can make an appropriate policy to advance the quality of education. Education is an open system and cannot be separated from problems such as micro which are problems that arise in the elements contained in education itself as a system such as curriculum problems, educational problems and so on and macro which are problems that exist in education as a system with other systems that have a wider scope in human life such as the problem of unequal education, low quality of education, problems of ability and so on. So that by discussing this educational problem, we can find out the point of the problem and try to provide solutions and solutions.
\end{abstract}

\footnotetext{
Abstrak

Artikel ini bertujuan untuk mengidentifikasi permasalahan pada pendidikan yang ada di Indonesia. Karena diharapkan dengan memahami permasalahan pendidikan yang terjadi bisa membuat suatu kebijakan yang tepat untuk memajukan mutu pendidikan. Pendidikan adalah suatu sistem yang terbuka dan tidak terlepas dari permasalahan seperti mikro yang merupakan masalah yang muncul pada unsur-unsur yang termuat pada pendidikan itu sendiri sebagai sebuah sistem seperti masalah kurikulum, masalah pendidikan dan lain sebagainya dan makro yang merupakan permasalahan yang terdapat pada pendidikan sebagai sebuah sistem dengan sistem lainnya yang cakupannya lebih luas pada kehidupan manusia seperti masalah tidak meratanya pendidikan, mutu pendidikan yang rendah, masalah kemampuan dan lain sebagainya. Sehingga dengan membahas tentang permasalahan pendidikan ini, kita bisa mengetahui titik permasalahannya dan berusaha untuk memberikan solusi dan jalan keluarnya.
} 


\section{PENDAHULUAN}

Seiring dengan perkembangan zaman yang begitu drastis pada dunia pendidikan yang akan terus memberikan perubahan kepada pola pikir manusia. Pendidikan merupakan sebuah sistem terbuka yang tidak terlepas dari suatu permasalahan, seperti masalah makro yang terjadi secara menyeluruh yang dialami hampir semua lembaga pendidikan pada proses pembelajarannya. Masalah ini muncul di sebabkan karena adanya keterbatasan sumber daya manusia, keterbatasan infrastruktur teknologi informasi dan pada sekarang ini permasalahan pendidikan yang terjadi di indonesia yaitu adanya kendala pada peningkatan mutu pendidikan. Kemudian masalah yang timbul pada komponen-komponen yang termuat pada pendidikan itu sendiri sebagai suatu sistem, seperti masalah kurikulum, masalah pendidikan, administrasi pendidikan dan sebagainya, masalah ini disebut dengan masalah mikro.

Berhubungan dengan permasalahan di atas yang kadang terjadi di indonesia. Permasalahan tersebut sering di duga bersumber dari guru, maka dari hal tersebut dengan cara mengidentifikasi permasalahan pada pendidikan kita harus mengetahui dimana titik permasalahan yang sebenarnya menjadi penyebabnya dan berupaya untuk memberikan jalan keluar atas permasalahan yang terjadi. Masalah pendidikan lainnya yang terjadi di indonesia seperti kualitas sumber daya manusianya sangat jauh bandingannya dengan sumber daya manusia Negara lain.

Kondisi pendidikan di indonesia sering dibanding-bandingkan dengan pendidikan di Negara-negara dunia lainnya, adanya faktor yang mempengaruhi pada keberhasilan peserta didiknya seperti peran orangtua yang memberikan dukungan positif, saran prasaran yang lengkap, perekonomian orangtua, peran guru, peran dari peserta didiknya sendiri dan faktor lain sebagainya. Dari keseluruhan faktor tersebut, faktor yang paling terpenting ialah faktor dari guru. Karena guru merupakan sosok untuk digugu dan ditiru, jadi guru adalah orang yang diberikan kepercayaan dan diharapkan mampu menjadi penyemangat juga stimulus supaya guru bisa meningkatkan mutu dan profesionalismenya.

Selain meningkatkan mutu dan keprofesionalannya, guru juga harus mempunyai kemampuan pedagogik, kepribadian, profesional dan sosial. Kemampuan itu merupakan kompetensi guru yang harus di tingkatkan untuk meningkatkan mutu dirinya sebagai guru juga 
mutu pada pendidikannya. Dan tujuan penulisan ini agar dapat mengidentifikasi permasalahan pendidikan di Indonesia.

\section{PERMASALAHAN PENDIDIKAN YANG SERING TERJADI}

Beberapa permasalahan pendidikan yang sering terjadi, diantaranya:

Adanya murid yang membludak atau jumlah peserta didik yang banyak membutuhkan pendidikan baik, sehingga pengelola pendidikan tidak mampu memenuhi tempat belajar yang baik, guru, saran dan prasarana, juga susah untuk meningkatkan mutu pendidikan. Kemudian kurangnya sumber daya dan dana untuk memenuhi berbagai keperluan yang dibutuhkan pendidikan, seperti pengadaan tenaga pendidik, buku, gedung, dan sarana pendidik juga biaya yang lainnya. Meski sumber daya dan dana ini melimpah tetapi dengan adanya murid yang membludak, kebutuhan juga semakin meningkat yang akhirnya sumber daya dan dana akan menipis.

Selain masalah di atas, biaya pendidikan yang mahal juga menjadi permasalahan. Karena untuk meningkatkan mutu pendidikan, mutu guru atau pendidiknya juga harus ditingkatkan agar guru tersebut bisa berfokus mengajar dan mendidik, bukan mencari kerja sampingan dan akhirnya badan kelelahan yang berakibat kurang semangat pada saat memberikan pembelajaran kepada peserta didiknya. Juga permasalahan selanjutnya adalah perekonomian yang rendah, yang mengakibatkan anak-anak putus sekolah dan mencari kerja untuk memenuhi biaya kehidupan sehari-harinya.

Kemudian masalah penempatan guru yang tidak sesuai dengan bidangnya. Dengan contoh pada sekolah A dimasukkan guru baru tetapi untuk mata pelajaran yang akan diajarkannya sudah penuh dan guru tersebut harus mengajar mata pelajaran lainnya diluar kemampuannya. Atau guru yang merangkap mengajar 2 mata pelajaran yang tidak berhubungan. Nah pada hal seperti ini, guru seharusnya mengajar sesuai dengan bidang studinya, karena jika tidak sesuai maka terjadinya keterbatasan guru yang menyebabkan bertambahnya tugas seorang guru.

\section{CARA MENGATASI PERMASALAHAN PENDIDIKAN}

Banyaknya permasalahan yang muncul pada dunia pendidikan, maka dari itu kita perlu mengidentifikasi permasalahan pendidikan yang terjadi agar bisa memberikan jalan keluar untuk permasalahan pendidikan ini. seperti dengan cara menyeleksi calon peserta didik, 
mengembangkan keterampilan tenaga pendidik melalui pelatihan-pelatihan yang sudah disediakan, menyempurnakan kurikulum yang materinya disesuaikan dengan muatan lokal di daerah setempat, mengembangkan sarana dan prasaran yang dapat menciptakan suasana belajar yang nyaman, aman, dan terntram, juga menyempurnakan administrasi sekolah sehingga dapat efisiensi anggaran.

\section{SIMPULAN}

Dunia pendidikan tidak lepas dari berbagai permasalahan yang datang, masalah makro dan mikro yang menjadi penghambat peningkatan mutu pendidikan. Selain masalah-masalah tersebut, guru lah yang di sebut sebagai sumber masalahnya. Karena guru merupakan orang yang sangat berpengaruh terhadap suksesnya keberhasilan pendidikan. Tetapi ada faktor lain yang membuat guru tidak bisa memaksimalkan kinerjanya. Seperti tidak sejahteranya guru, sarana prasana yang tidak memadai dan lain sebagainya. Permasalahan itu semua bisa diatasi dengan meningkatkannya kesejahteraan guru, memenuhi sarana prasana untuk pembelajaran dan lain sebagainya yang tujuannya untuk meningkatkan mutu pendidikan.

\section{REFERENSI}

Abbas, E. W. (2015). Pendidikan IPS Berbasis Kearifan Lokal. WAHANA Jaya Abadi.

Abbas, E. W. (2020). Menulis Artikel Jurnal. Menulis Artikel Jurnal.

Afifah, N. (2017). Problematika pendidikan di Indonesia. Elementary: Jurnal Ilmiah Pendidikan Dasar, 1(1), 41-47.

Anis, M. Z. A., Putro, H. P. N., Susanto, H., \& Hastuti, K. P. (2020). Historical Thinking Model in Achieving Cognitive Dimension of Indonesian History Learning. PalArch's Journal of Archaeology of Egypt/Egyptology, 17(7), 7894-7906.

Indriyani, I. E., Syaharuddin, S., \& Jumriani, J. (2021). Social Interaction Contents on Social Studies Learning to Improve Social Skills. The Innovation of Social Studies Journal, 2(2), 93-102. 
Jumriani, J., Mutiani, M., Putra, M. A. H., Syaharuddin, S., \& Abbas, E. W. (2021). The Urgency of Local Wisdom Content in Social Studies Learning: Literature Review. The Innovation of Social Studies Journal, 2(2), 103-109.

Kurniawan, R. Y. (2016). Identifikasi permasalahan pendidikan di Indonesia untuk meningkatkan mutu dan profesionalisme guru. Konvensi Nasional Pendidikan Indonesia, 14151420.

Nasution, E. (2016). Problematika pendidikan di Indonesia. Mediasi, 8(1). 